225

Received: Fevruary 28, 2016

Accepted: March 31, 2016
Macedonian Journal of Animal Science, Vol. 6, No. 2, pp. 125-130 (2016)

In print: ISSN $1857-6907$

On line: ISSN $1857-7709$

UDC: $334.722: 332.14 / .15(497.7-18)$

Original scientific paper

\title{
THE RURAL DEVELOPMENT IN THE NORTHEAST PLANNING REGION IN THE REPUBLIC OF MACEDONIA THROUGH ENTREPRENEURSHIP
}

\author{
Tošo Kostadinov \\ Ss. Cyril and Methodius" University in Skopje, Institute of Animal Science, \\ Blvd. Ilinden, 92A; P.O. box. 207, 1000 Skopje, Republic of Macedonia, \\ tosokostadinov@gmail.com
}

\begin{abstract}
The aim of this paper is to incorporate new findings in the body of knowledge regarding entrepreneurship in rural areas of the Northeast Planning Region in the Republic of Macedonia. In that view interviewing was conducted with 16 owners of SMEs in rural areas who were presented four sets of statements that are important for understanding of the situation with entrepreneurship in rural areas of the Northeast Planning Region in the Republic of Macedonia valued at five-degree scale from irrelevant to that of priority. One of the conclusions, by which the state of entrepreneurship and SMEs in rural areas of the Northeast Planning Region of the Republic of Macedonia is assessed, based on empirical research and compared with the results of an identical research on rural entrepreneurship on the territory of the Republic of Macedonia, is that the rural entrepreneur from that region of the country has a nonsatisfying entrepreneurial qualities required by the developed business world in terms of commitment, desire for independence, flexibility etc. Development priorities for the Northeast Planning Region for the coming period are: 1) Economic growth higher than the average national growth. 2) Modern international infrastructure, constructed with support from national and European funds. 3) Environmental protection - investment for the our descendants. 4) Agricultural development based on modern knowledge and innovation. 5) Rural development and development of tourism - new challenges for better living in the rural areas. 6) Developed social infrastructure and service - key to a better quality of life.
\end{abstract}

Key words: Northeast planning region in the Republic of Macedonia; rural entrepreneurship; rural entrepreneurs; SMEs; rural area

\section{РУРАЛНИОТ РАЗВОЈ ВО СЕЕВЕРОИСТОЧНИОТ ПЛАНСКИ РЕГИОН ВО РЕПУБЛИКА МАКЕДОНИЈА ПРЕКУ ПРЕТПРИЕМНИШТВО}

Целта на овој труд е да се вклучат нови наоди во тело на знаење за претприемништвото во руралните области на североисточниот регион планирање во Република Македонија. Во тој поглед интервјуирање е спроведена со 16 сопственици на мали и средни претпријатија во руралните области кои беа презентирани четири групи на извештаи кои се важни за разбирање на ситуацијата со претприемништвото во руралните области на североисточниот регион планирање во Република Македонија во вредност од пет-степен скала од несоодветни на онаа на приоритет. Еден од заклучоците, со што состојбата на претприемништвото и малите и средни претпријатија во руралните области на североисточниот регион на Република Македонија се оценува врз основа на емпириски истражувања и во споредба со резултатите од идентична истражување на руралните претприемништвото на територијата на Република Македонија, е дека руралните претприемач од тој регион на земјата има не-задоволувчки претприемачки квалитети потребни од страна на развиените бизниси во однос на посветеност, желба за независност, флексибилност и др. Развојни приоритети на Североисточниот плански регион во наредниот период се следниве: 1) 1. Економски раст повисок од просечниот националниот раст. 2) Современа меѓународни инфраструктура, изградена со поддршка од национални и европски фондови. 3) Заштита на животната средина - инвестиција за нашите потомци. 4) Земјоделски развој врз основа на модерната наука и иновации. 5) Рурален развој и развој на туризмот - нови предизвици за подобар живот во руралните средини. 6) Развиена социјална инфраструктура и услуги - клучни за подобар квалитет на живот.

Клучни зборови: Североисточен плански регион во Република Македонија; рурално претприемништво; рурален претприемач; МСП; рурални подрачја 


\section{INTRODUCTION}

The Northeast Planning Region consistc of the municipalities in the far north-eastern part of the country, along the borders with Kosovo, Serbia and Bulgaria. The total area of the region is 2.310 sqkm, i.e. $9 \%$ of the total territory of the Republic of Macedonia.

This planning region consists of 6 municipalities with 174.876 inhabitants. Most (189) of the settlements (192) are rural and the population density of 75 inhabitants/sqkm is close to the national average (82).

The planning region is characterized by strong internal discrepancies in the demographic development. One half of the municipalities suffer population decline (Rankovce, Staro Negorichane and Kratovo), one is characterised by low- (Kriva Palanka), and two by high population growth (Lipkovo and Kumanovo)

Communication with neighboring countries is conducted through three border crossings: Tabanovce-Kumanovo and Prohor Pchinski-Staro Nagorichane with Serbia, and Deve Bair-Kriva Palanka with Bulgaria.

The Osogovo mountain massif is one of the most important mining areas in the Republic Macedonia, with mineral deposits of copper, lead, chrome, arsenic, antimony and zinc. The Toranica mine (Kriva Palanka) is a rich geological site, with ore reserves (lead, zinc, copper and silver) estimated at 50 years of normal exploitation, and the mine Lojane (Lipkovo) is rich in arsenic, antimony and chrome. There are several sites with non-metals deposits in the planning region (smectite clay, tufa, quartz, diatomaceous earth and send deposits), particularly in the municipality of Kratovo, with deposits sufficient for 50 years of exploitation.

The planning region includes the catchment area of the rivers Pchinja and Kriva Reka, with abundant sources of water (especially in the Osogovo region), two scenic accumulation lakes (Lipkovo and Glazhnja in the municipality of Lipkovo) and two smaller accumulation lakes (Bazjacko Brdo and Vlashki Kolibi in Kriva Palanka).

For the purposes of using the water resources of Zletovska River, construction of the regional multi-purpose hydro-system Zletovica (for the East and the Northeast Region) is underway, which will provide drinking water for more than 200.000 inhabitants.
The planning region is not specialized in growing specific agricultural crops and production does not achieve high yields. Organic crops grown in the region are lately accompanied by organic livestock production, due to the large area under meadows and pastures that make this region favourable for development of animal husbandry. Gathering forest berries, fungi, medicinal plants and other plants is becoming a source of additional income for the population.

Churches and mosques, as well as the monastery complexes are of special significance for the planning region. The Osogovo monastery, the monastery in the village of Matejche, the church Sv. Gjorgi (Saint George) in Staro Negorichane, the Tatar Sinan Pasha mosque in Kumanovo city centre from the 16 century, the mosque in Tabanovce built in the 13 century etc.; the historical, architectural and spiritual importance of the churches and monasteries in greater that that of those which are already being used as tourist attractions. Furthermore, the astronomical observatory Kokino, the archeological sites Kuklica and Gradishte, the old town architecture in Kratovo, as well as the several nature reserves (Ploche Litotelmi, as a strict natural reserve containing the only population of the relict crustacean species Chirocephalus pelagonicus in the world) and the nature monuments, make the planning region unique in its abundance of natural and cultural heritage, and give it a competitive advantage in comparison with other regions, not only because of its position near to the borders.

The Astronomical observatory Kokino dates from 1.800 BC (early Broze Age) and is one of the most valuable ancient observatories in the world. The American National Aeronautics and Space Administration NASA ranked Kokino fourth on the list of 15 such observatories in the world, after Abu Simbel in Egypt, Stonehenge in England, and Angkor-Wat in Cambodia. The fact that this site is so unique is important, but - still - further investment in the site is needed, so that its full potentials may be exploited.

The Northeast Planning Region has a per capita GDP of $1.707 €$, which is. $47.7 \%$ below the national average for the Republic of Macedonia. The planning region contributes the smallest absolute value to the national GDP of all planning regions (only 4.5\%), and is second last according to the level of development. Most significant industries in that planning region are: food and metal processing industry, along with the chemical industry and trade. 
Development priorities of the Northeast Planning Region for the coming period are:

1. Economic growth higher than the average national growth.

2. Modern international infrastructure, constructed with support from national and European funds.

3. Environmental protection - investment for the our descendants.

4. Agricultural development based on modern knowledge and innovation.

5. Rural development and development of tourism - new challenges for better living in the rural areas.

6. Developed social infrastructure and service - key to better quality of life.

\section{MATERIALS AND METHODS}

The aim of this research is based upon relevant literature, documents and particularly an analysis of relevant sample of interviews (owners of 16 SMEs) to observe the conditions of the rural entrepreneurship in rural parts of the South-East
Planning Region. The comparison of the obtained results with those relevant to the rural pats on the whole territory of the Republic of Macedonia (interviewed suitable sample of owners of 101 SMEs) puts more light on the entrepreneurship in the researched region.

Several commonly used methods of economic analysis were applied in the composition of this paper, primarily the method of generalization and specialization, the method of induction and deduction, statistical method and the comparative method.

\section{RESULTS AND DISCUSSION}

Four sets of statements (valued at a five-degree scale from 1 - unimportant to 5 - priority) that are of relevance to the efforts to perceive the situation of rural entrepreneurship were presented to survey respondents in the Southeast Planning Region of Republic of Macedonia, (Table 1, 2, 3 and 4).

The results are compared to those obtained from rural areas on the territory of the Republic of Macedonia.

Table 1

Degree of agreement with the statements in terms of constraints on the development of enterprises, using the arithmetic means

\begin{tabular}{|c|c|c|}
\hline & Mean va & ue (rural areas) \\
\hline & $\begin{array}{l}\text { Republic of } \\
\text { Macedonia }\end{array}$ & $\begin{array}{c}\text { Northeast planning } \\
\text { region }\end{array}$ \\
\hline High rate of VAT & 3.60 & 3.82 \\
\hline Problems with collection of claims & 3.65 & 3.70 \\
\hline High rates of tax and employee contributions & 4.18 & 4.17 \\
\hline Administrative difficulties and complex of procedures & 3.99 & 4.11 \\
\hline Instability and ambiguity of the legislation & 4.02 & 4.19 \\
\hline High interest rates on loans & 4.28 & 4.38 \\
\hline Cost of energy & 3.92 & 4.15 \\
\hline Cost of material, raw materials & 3.80 & 3.96 \\
\hline Availability of funding sources & 3.99 & 4.22 \\
\hline Loss of market in the former Yugoslavia & 3.03 & 3.13 \\
\hline Unfair competition & 3.70 & 3.86 \\
\hline Domestic competition & 3.86 & 3.98 \\
\hline Obsolete technology & 3.40 & 3.53 \\
\hline Quality of products & 3.30 & 3.54 \\
\hline Products prices & 3.32 & 3.50 \\
\hline Labour costs & 3.32 & 3.64 \\
\hline Non-innovative products & 3.12 & 3.20 \\
\hline Lack of funds for research and development & 2.84 & 2.95 \\
\hline
\end{tabular}


Respondents indicated high interest rates on loans, high tax rates and contributions for employees, all that in an environment of limited availability of sources of funding as major obstacles to development activities in enterprises. However, com- pared to data obtained from SMEs in rural areas of the whole territory of the Republic of Macedonia, in rural SMEs of the Northeast Planning Region these obstacles are somewhat more emphasized.

Table 2

Degree of agreement with the statements related to improvement of the competitiveness on the market using arithmetic means.

\begin{tabular}{llc}
\hline \hline & Mean value (rural areas) \\
& $\begin{array}{c}\text { Republic } \\
\text { of Macedonia }\end{array}$ & $\begin{array}{c}\text { Northeast } \\
\text { planning region }\end{array}$ \\
\hline Improving the quality of products and services & 4.17 & 4.11 \\
Improving the promotion of products & 4.20 & 4.03 \\
Obtaining quality certifications & 4.03 & 3.9 \\
Professional consulting assistance & 3.46 & 3.34 \\
Improvement and education in the field of entrepreneurship & 3.83 & 3.76 \\
Improvement and education in the field of IT & 3.88 & 3.76 \\
Improvement and education in the field of management & 3.83 & 3.73 \\
Improvement and education in finance & 3.65 & 3.51 \\
Improvement and education in the field of sales & 3.89 & 376 \\
Improvement and education in marketing & 3.91 & 4.83 \\
Improvement and education in foreign languages & 3.38 & 3.28 \\
Association with companies in the sector for joint appearance on the market & 3.37 & 3.19 \\
Assistance from development programs through grants & 4.31 & 4.21 \\
Assistance from development programs through favorable loans & 4.30 & 3.69 \\
Assistance from development programs through guarantee funds & & 4.16 \\
\hline \hline
\end{tabular}

Source: own calculations

The most important measures regarding promoting of enterprise competition on the market are development assistance programs through grants, development assistance programs through favorable loans, improving the promotion of products and the quality of products/services. Respondents are aware of the benefit of obtaining/ having certificates of quality.

Compared with the results from the survey of SMEs in rural areas throughout the territory of the Republic of Macedonia, SMEs in rural areas of the Southeast Region, however, seem to be less competitive.

The results of the comparative analysis have shown that owners have expressed a lower degree of consideration regarding future plans for their own businesses of SMEs (Northeast Planning Region) than their average counterparts from rural areas of the Republic of Macedonia.

As a whole, the responses to the set of questions regarding attitudes towards entrepreneurship indicate relatively positive attitudes towards entrepreneurship. However, the responses of SMEs in rural areas of the Northeast Planning Region indicate that the attitudes towards entrepreneurship among SMEs in that region are less positive than the views expressed by respondents from SMEs in rural areas throughout the territory of the Republic of Macedonia. 
Table 3

Degree of agreement with claims regarding plans for the business future (arithmetic means)

\begin{tabular}{lcc} 
& \multicolumn{2}{c}{ Mean value (rural areas) } \\
& Republic of Macedonia & Northeast planning region \\
Introducing new products or services & 4.08 & 3.98 \\
Sales on a new market & 3.37 & 3.12 \\
Exploring new markets & 3.32 & 3.16 \\
Search for new distribution channels & 3.61 & 3.52 \\
Expanding advertising and promotion & 3.87 & 3.66 \\
Investing in new equipment and machinery & 3.69 & 3.57 \\
Replacement of current equipment and machinery & 3.73 & 3.56 \\
Expansion of current facilities & 3.68 & 3.57 \\
Redesign/new arrangement of the current facilities & 3.42 & 3.34 \\
Search for additional financial capital & 3.92 & 3.86 \\
Computerization of current operations & 3.29 & 3.13 \\
Upgrading of computer systems & 3.38 & 3.28 \\
Redesign of work activities & 3.29 & 3.12 \\
Expanding the scope of work activities & 3.77 & 3.66 \\
Search for professional or technical advice & 3.45 & 3.32 \\
Additional engagement of staff specialists & 3.37 & 3.32 \\
Investing in staff training (elsewhere / not in the & 2.63 & 2.48
\end{tabular}
company)

Source: own calculations

Table 4

Degree of agreement with the statements in terms of attitudes to entrepreneurship, using the arithmetic means

\begin{tabular}{llc}
\hline \hline & \multicolumn{1}{c}{ Mean value (rural areas) } \\
\cline { 2 - 3 } & $\begin{array}{c}\text { Republic of } \\
\text { Macedonia }\end{array}$ & $\begin{array}{c}\text { Northeast } \\
\text { planning region }\end{array}$ \\
\hline My business is the most important activity in my life & 4.13 & 4.02 \\
I would do everything that is needed for my business to succeed & 4.18 & 4.02 \\
I plan to sell my business at the end & 2.15 & 2.36 \\
I would like to significantly contribute to the community by developing a successful business & 4.29 & 4.12 \\
I would prefer to have my own business than to earn higher wages working for someone else & 4.78 & 4.56 \\
To run your own business is more important than have more time for the family & 3.80 & 3.65 \\
I would prefer to have my own business than to have another promising career & 4.08 & 3.90 \\
For the entrepreneur it is important to understand and accept the risk in order to start and run & 4.26 \\
$\quad$ a successful business & 3.70 & 4.13 \\
I am ready to get into conflict with my family for the sake of running my business & 3.52 \\
I would put my house mortgaged to acquire capital for my business & 3.67 \\
I would be ready to have less security for my family in order to run my business & 3.34 & 3.57 \\
I run my business to continue the family tradition & 3.52 & 3.36 \\
I run my business to contribute to the welfare of my relatives & 3.47 \\
I run my business to live in a place that my family likes & 4.02 \\
I run my business to improve the status and prestige of my family & 4.08 \\
I run my business to have more flexibility in my personal and family life & 3.23 \\
\hline \hline
\end{tabular}

Source: own calculations 


\section{CONCLUSION}

High interest rates on loans, high tax rates and contributions for employees, all that in an environment of limited availability of sources of funding were indicated by respondents as major obstacles to development activities in enterprises. However, compared to the data obtained from SMEs in rural areas of the whole territory of the Republic of Macedonia, in SMEs in rural areas of the Northeast Planning Region these obstacles are somewhat more emphasized.

Most important measures regarding promoting of enterprise competition on the market are development assistance programs through grants, development assistance programs through favorable loans, improving the promotion of products, and the quality of products/services. Respondents are aware of the benefit of obtaining/ having certificates of quality.

In comparison with the results from the survey of SMEs in rural areas on the whole territory of the Republic of Macedonia, SMEs in rural areas of the Southeast Region still seem to be less competitive.

The results of the comparative analysis have shown that owners have expressed a lower degree of consideration regarding future plans for their own businesses of SMEs (Northeast Planning Region) than their average counterparts from rural areas of the Republic of Macedonia.

Generally speaking, the responses to the set of questions regarding attitudes towards entrepreneurship indicate relatively positive attitudes towards entrepreneurship. However, the responses of SMEs in rural areas of the Northeast Planning Region indicate that the attitudes towards entrepreneurship among SMEs in that region are less positive than the views expressed by respondents from SMEs in rural areas throughout the territory of the Republic of Macedonia.
Development priorities of the Northeast Planning Region for the coming period are the following:

1. Economic growth higher than the average national growth.

2 Modern international infrastructure, constructed with support from national and European funds.

3. Environmental protection - investment for the our descendants.

4. Agricultural development based on modern knowledge and innovation.

5. Rural development and development of tourism - new challenges for a better life in rural areas

6. Developed social infrastructure and service - key to a better quality of life.

\section{REFERENCES}

[1] Belak, Janko, et al. (1993): Podjetništvo, politika podjetja in menagement, Založba Obzorja, Maribor.

[2] Burns, P. (2001): Enterprise and Small Business, Palgrave Macmillan, London.

[3] Bygrave, D. W., Zacharakis A.: The portable MBA in Entrepreneurship, fourth edition, John Wiley\&Son. Inc: Hoboken, New Jersey.

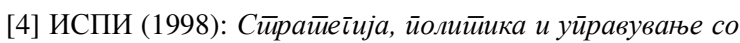

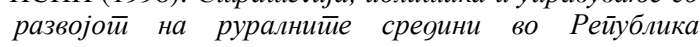
Макеgонија, Трибина македонска, Скопје.

[5] Kostadinov, T., Cilev, G., Nikolova N. (2008): Small and Medium-Sized Enterprises in the Field of Agriculture in the Republic of Macedonia between Competitiveness Based Strategies and the Blue Ocean Strategy, Proceedings. International Conference for Entrepreneurship Innovation and Regional Development, Skopje-Ohrid.).

[6] Kostadinov,T..(2011): Влијаниет̄о на иррейириемниити-

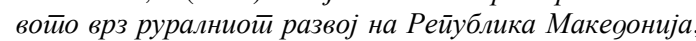
докторска дисертација, Економски институт, Скопје

[7] Pavić, Ž. (2008): Poduzetništvo mladih i nova ekonomija, Ekonomski vjesnik, No. 1-2, Zagreb.

[8] Carter, Sara Jones-Evans Dylan (2000): Enterprise and Small Business, Prentice Hall, London.

[9] Siropolis N. C. (1995): Menadžment malog poduzeća, 4 izdanje, MATE, Hrvatska Obrtnička komora, Zagreb. 